\title{
Exploring the Determinants of Financial Development (Using Panel Data on Developed and Developing Countries)
}

\author{
SYED HASSAN RAZA ${ }^{1}$, HINA SHAHZADI ${ }^{2}$, MISBAH AKRAM ${ }^{1, *}$ \\ ${ }^{1}$ Department of Economics, National University of Modern Languages Faisalabad Campus, Pakistan \\ ${ }^{2}$ M.Phil Scholer Department of Economics Gc University Faisalabad, Pakistan \\ *Corresponding author: misbahakram55@yahoo.com
}

Received July 22, 2014; Revised July 30, 2014; Accepted August 05, 2014

\begin{abstract}
This research paper investigates the determinants of financial development. Credit to private sector is used as proxy of financial development in this study. Panel data from 1990 to 2012 on 27 developed and 30 developing countries has been used. The main interest of the research paper is to explore how different variables or indicators affect the credit to private sector as percentage of GDP (CPS) (We use credit to private sector as percent of GDP (CPS) as proxy of financial development.). The Hausman test is used to check weather fixed effect model is more appropriate or random effect model. Hausman test is in favor of Fixed Effect Model. The role of different important variables which effect the financial development have been found by using fixed effect model. It is concluded from empirical results that all exogenous variables except NFDI and RL have significant effect on financial development.
\end{abstract}

Keywords: credit to private sector, financial development, panel data analysis, fixed effect model, hausman test

Cite This Article: SYED HASSAN RAZA, HINA SHAHZADI, and MISBAH AKRAM, "Exploring the Determinants of Financial Development (Using Panel Data on Developed and Developing Countries)." Journal of Finance and Economics, vol. 2, no. 5 (2014): 166-172. doi: 10.12691/jfe-2-5-6.

\section{Introduction}

The importance of financial development and economic growth have become more pronounced in recent years; in addition to other vital factors, the long term economic growth and welfare are correlated with the degree of financial development. There are different indicators to measure financial development such as size, depth, access, efficiency and stability of a financial system. The financial systems include markets, intermediaries, range of assets, institutions and regulations. A strong financial system guarantees the high capital accumulation (the rate of investment), trading, hedging, insurance services, diversified saving and portfolio choices etc. which facilitate and encourage the inflow of foreign capital and technological innovation. The greater financial development leads to poverty reduction, income inequality, mobilization of savings, better access of the poor to finance, high return investment, promotion of sound cooperate governance and enhancement of economic growth as well as welfare.

The key importance of financial development and economic growth is generally acknowledged in the literature. However, the area of public sector borrowing from domestic banks and its impact on financial development and credit to private sector is still underresearch. The public debt is often seen as a burden for both developing and developed countries. Since the early 1990s, there has been a fiscal improvement in both developing and developed countries due to restricted public debt; however, the fiscal adjustment in developed countries has been more noticeable than developing countries (World Economic Outlook, 2001).

In recent years, the public debt in advanced countries has been falling while the emerging market countries do not follow the same trend. It is because advanced countries preferred to give credit to private sector than the public sector to avoid the crowding out situation. The crowding out situation limited the excess of private sector on credit from domestic banks both in developed and developing countries. The supply and demand of credit to the public and private sectors depends upon the macroeconomic conditions. If the level of public debt is high in the economy and macroeconomic variables indicate that the country's economic situation is vulnerable, domestic banks may be expected to prefer to finance public sector instead of private sector, which is more risky borrower. Thus, the private sector credit by the domestic banks may decline in such economies (IMF, Research Department, 2004),

The credit to private sector is essential for the private investment and development in an economy. The domestic banks play a pivotal role in increasing employment, efficiency, productivity and inducing growth in an economy. However, in large emerging countries than advanced ones, the domestic banks mostly prefer to 
finance public sector to private sector. Thus, the private sector faces problems in finding credit for investment in form of crowding out systematically (Caballero and Krishnamurthy, 2004).

The importance of financial sector cannot be denied as efficient financial system is a perquisite condition for rapid economic growth. On one side the well-organized financial sector escalates the inflow of capital, availability of financial services, improve saving and efficient allocation of credit in economy while on the other side the same factors help to improve GDP growth rate. The credit to private sector can be taken as a proxy of development in financial sector.

In this research report, our objective is to explore the antecedents of credit to private sector using panel data on 27 developed and 30 developing countries from the period 1990-2012.

\section{Literature Review}

Anthony and Frank (2013) studied the commercial bank's credit rationing behavior in Ghana. The log it model was used and odd ratios were calculated. The results suggested that even though interest rates might be liberalized to ensure the proper credit allocation, the commercial banks would still ration out credit due to moral hazards \& adverse selection. It was therefore suggested, that government and central bank should play their active role in the financial sector and forced the commercial banks to improve their credit systems to reduce default rate rather than using the traditional methods.

Rubaszek and Serwa (2012) formulated a life cycle model for credit to household sector and linked it with individual income uncertainty. The dynamic life-cycle general equilibrium model is used for 36 countries from period 1990-2005. The results showed that decrease in deposit and savings from individuals and rising spread rate persistently reduced the level of credit to household sector.

Djankov et. al (2005) tried to estimate the determinants of private credit by using date set on legal creditor's rights and registration of private and public credit in 129 countries. The study found that both creditors' protection through the legal system and information sharing institutions were associated with higher ratios of private credit to GDP, but that the former was relatively more important in the richer countries. An analysis of legal reforms also showed that credit to private sector arose after improvements in creditor's rights and in information sharing.

Rotherford (2000) quantified the socioeconomic characteristics of financial sector in 38 Sub Saharan African countries. The study found that the range of financial products was limited and became a big hurdler in banking sector growth. The study calculated different money multiplier and then linked them with banking sector growth.

Kosmidou et al (2002) studied the interrelationship between bank performance, financial structure and macroeconomic indicators. The study used unbalanced panel data on 32 commercial banks and stock market during the period 1995-2002 in U.K. The study found that the banks had to compete with NFBIs and stock market in rapidly challenging environment. The proxies of bank performance as Return of Average Asset, Return of Equity and Net Interest Margin, Capital, Cost to income ratio suggested that only cost efficient and well equipped banks could grow faster. Further, the rising GDP growth rate and low inflation positive affected the bank performance.

Yassin (2012) analyzed financial health of 25 insurance companies in Jordan from 2002 -2007. The study used leverage, liquidity, age, size and management competitive index to measure their performance. The time series analysis depicted that managerial skills, investment opportunities and normal profits made them competitive markets. Moreover, the presence of insurance companies not only improved the role of financial sector but also enhance economic growth and well being through proper allocation of financial resources.

Maleya (2013) studied the financial health of listed companies during the 2006-2012 in Kenya. Most of the firms took financial facility from banks in short run to fulfill their current and operational expenses. The study found that the size, age, return on assets, liquidity had positive effect on firm's performance. However, the increasing leverage, debt and operating cost level led to firm towards bankruptcy and diseconomies of scales. In this situation, the firms focused on stock market for financial assistance that would be made them cost effective, competitive and stable in long run.

\section{Data and Methodology}

The research paper used the balanced panel data on the sample consisting of 27 developed and 30 developing countries from the period 1990-2012. The following model is formulated to determine the impact of different variables on Credit to Private Sector as percentage of GDP:

$$
\begin{aligned}
& C P S_{i t}=f\left(P O P G_{i t}, A G R I_{i t}, G D P G_{i t}, T_{O P E N N E S S},\right. \\
& \left.N F D I_{i t}, G S C_{i t}, D E M_{i t}, R L_{i t}\right)
\end{aligned}
$$

Where

CPS $=$ credit to private sector as percent of GDP

POPG = population growth

AGRI = share of agriculture sector in GDP

GDPG= real GDP growth

TOPENNESS = trade openness which is the sum of exports and imports as percent of GDP GDP

GSC = government current spending as percent of GDP $\mathrm{DEM}=$ index of democracy

$\mathrm{RL}=$ index of rule of law

The model of this study is:

$$
\begin{aligned}
& \text { CPS }_{i t}=\alpha_{1 i}+\alpha_{2} \text { POPG }_{i t}+\alpha_{3} \text { AGRI }_{i t} \\
& +\alpha_{4} \text { GDPG }_{i t}+\alpha_{5} \text { TOPENNESS }_{i t}+\alpha_{6} N{ } I_{i t} \\
& +\alpha_{7} G C_{i t}+\alpha_{8} \text { DEM }_{i t}+\alpha_{9} R L_{i t}+\varepsilon_{i t}
\end{aligned}
$$

$\mathrm{i}$ stands for the $\mathrm{i}^{\text {th }}$ cross-sectional individual (i.e. country) and $t$ for the $t^{\text {th }}$ time period.

It is often of interest to examine the relationship between the variables by using cross-sectional and timeseries data together by longitudinal or panel data sets. The main advantage of panel data is that one can increase the 
number of degrees of freedom and power of the test by employing more information on the behavior of a large number of entities at the same time. The additional advantages of panel data are to mitigate problems of multicollinearity that may arise if time-series are modeled individually and presence of heteroscedastcity in cross sectional data. The panel data set addressed these problems efficiently. However, the Heterogeneity across entities/units is central issue when we analyzed the panel data. The report uses the two most prominent estimation techniques (Fixed Effect Model and Random Effect Model) to resolve the heterogeneity. The panel Fixed Effect Model is:

$$
y_{i t}=\alpha_{i}+\beta x_{i t}+e_{i t}
$$

$\mathrm{i}=1,2,3 \ldots . .57 \mathrm{t}=23$

$\alpha_{\mathrm{i}}=$ Intercept for each entity

$\beta=$ slope of panel regression line and same for all entities

$\mathrm{x}_{\mathrm{it}}=$ independent variables

$\mathrm{e}_{\mathrm{it}}=$ error term

If individual country effect $\alpha_{\mathrm{i}}$ (cross-sectional or time specific effect) does not exist, the Ordinary Least Squares (OLS) produces efficient and consistent parameters/estimates. As there is the problem of heterogeneity in the panel data, the OLS estimators is no longer BLUE. Then the most appropriate method is Pooled Ordinary Least Square to produce efficient and consistent parameters/estimates.

The Fixed Effect Model (FEM) also referred as the "Least-Squares Dummy Variable (LSDV) model" estimates the intercepts (as coefficient of dummy variables)for $\mathrm{n}-1$ units. This model allows intercepts to vary for each cross-section and thus accounts for the individual effect. The FE estimation controls the unitspecific heterogeneity by eliminating (demeaned values) all time-constant information for each individual $i^{\text {th }}$ from the data. Moreover, the addition of dummies for all entities expect for one increase the degree of freedom with the alphas pool across entities/units, so in essence, we have $n$ parallel regression lines.

In Fixed Effect Model (FEM), the null hypothesis is that all of the units/entities share the same intercept. The alternative is that they have different intercepts across units. This is tested and compared by a joint F-test statistics. However, sometimes the different unit's intercepts may pick up a random error and thus be inconsistent.

The Random Effect Model (REM) estimates when unobserved heterogeneity is uncorrelated with any one of the explanatory variable in the model. In other words, $\boldsymbol{a}_{\boldsymbol{i}}$ is a sort of random disturbance at the individual level. The Random Effect model is:

$$
y_{i t}=\alpha_{o}+\beta_{j} x_{i t}+a_{i}+e_{i t}
$$

$\alpha_{0}=$ Intercept same for all entities

$\beta_{\mathrm{j}}=$ different slope for each entity

$\mathrm{X}_{\mathrm{it}}=$ independent variables

$a_{\mathrm{i}}=$ unobserved variable

$\mathrm{e}_{\mathrm{it}}=$ error term

In Random Effect Model, if $a_{i}$ is uncorrelated with any of the explanatory variables then $\beta_{\mathrm{j}}$ can be consistently estimated for a single cross-section and there is no need to use for panel data. However, this model may loss much useful information about the entities in the other time periods.

The appropriate model estimation strategy is based on the $a_{i}$ as parameters to be estimated infixed effect method or $a_{i}$ as random variable uncorrelated with the explanatory variables in random effect model. The $\mathrm{FE}$ and $\mathrm{RE}$ estimators can be compared through a test whether there is correlation/uncorrelation existed between $a i$ and $\mathrm{X}_{\mathrm{it}}$ across all time periods or not. The Hausman (1978) can tell us about the appropriate model.

The Hausman test is used to test either RE estimators or FE estimators are consistent. If $a_{i}$ is uncorrelated with the explanatory variables, in this case, RE estimators are more efficient than $\mathrm{FE}$ estimators. If $a_{i}$ unobserved heterogeneity is correlated with the independent variables in the case, RE estimators are biased, while FE estimators are consistent. The hypothesis is formulated the following way under Hausman test as:

$\mathrm{H}_{0}$ : Corr $\left(a_{i}, \mathrm{x}_{\mathrm{j}}\right)=0 \mathrm{RE}$ estimators are more efficient than FE estimators.

$\mathrm{H}_{1}$ : Corr $\left(a_{i}, \mathrm{x}_{\mathrm{j}}\right) \neq 0 \mathrm{FE}$ estimators are more efficient than RE estimators.

\section{Results and Discussions}

This section consists of empirical analysis. The results/estimations are presented with tables and explanations below:

First we explored the descriptive statistics of our panel data in Table 1 and Table 2:

The Table 1 shows the mean value of all the variables used in the analysis during the period 1990 to 2012 for each country. During 1990-2012, Thailand's mean credit to private sector as percentage of GDP is 117.90, mean population growth rate is 0.8 , mean share of ARGI in GDP is 10.6, mean GDPG 4.7, mean TOPENESS as percentage of GDP is 107.6, mean NFDI as percentage of GDP is 3.0, mean GSC as percentage of GDP is 0.1 , mean DEM index is 6.4 and mean RL index is 0.2. China's average credit to private sector as percentage of GDP is 107.88 , mean population growth rate is 0.8 . mean share of ARGI in GDP is 15.7, mean GDPG 10.0, mean TOPENESS as percentage of GDP is 51.4, mean NFDI as percentage of GDP is 3.8, mean GSC as percentage of GDP is 0.1, mean DEM index is -0.7 and mean RL index is -0.4 Pakistan's average credit to private sector as percentage of GDP is 24.30 , mean population growth rate was 2.2 mean share of ARGI in GDP is 23.80, mean GDPG 4.2, mean TOPENESS as percentage of GDP is 32.7, mean NFDI as percentage of GDP is 1.3 , mean GSC as percentage of GDP is 0.1 , mean DEM index is 2.5 and mean RL index is -0.7 .

The Table 2 shows the total number of observations is 1311 as there are 57 countries and 23 time periods. The overall statistics shows in all panels mean of credit to private sector as a percentage to GDP (CPS) is 172.1862, standard deviation 960.9384 units, minimum value 1.166 and maximum value is 15788.26 . The between statistics shows the value between the panels i.e. countries, for example, 751.5921 units is the standard deviation of CPS, the minimum value is 6.546282 and the maximum value is 5736.89 during the period 1990-2012. Similarly, the 
within statistics shows the standard deviation of CPS, the country during the period 1990-2012. minimum value and the maximum value for any specific

Table 1. Descriptive Statistics- Mean Values- All Countries

\begin{tabular}{|c|c|c|c|c|c|c|c|c|c|}
\hline $\begin{array}{l}\text { COUNT- } \\
\text { RIES }\end{array}$ & $\begin{array}{l}\text { MEAN } \\
(\mathrm{CPS})\end{array}$ & $\begin{array}{l}\text { MEAN } \\
\text { (POPG) }\end{array}$ & $\begin{array}{l}\text { MEAN } \\
\text { (AGRI) }\end{array}$ & $\begin{array}{l}\text { MEAN } \\
\text { (GDPG) }\end{array}$ & $\begin{array}{c}\text { MEAN } \\
\text { (TOPENNESS) }\end{array}$ & MEAN(NFDI) & MEAN(GSC) & MEAN(DEM) & $\operatorname{MEAN(RL)}$ \\
\hline Algeria & 13.4 & 1.8 & 9.6 & 2.6 & 56.0 & 0.9 & 0.2 & -1.5 & -0.9 \\
\hline Argentina & 17.0 & 1.1 & 7.7 & 4.7 & 21.7 & 2.4 & 0.1 & 7.6 & -0.4 \\
\hline Australia & 92.4 & 1.3 & 3.3 & 3.2 & 33.7 & 2.6 & 0.2 & 10.0 & 1.7 \\
\hline Austria & 105.0 & 0.5 & 2.2 & 2.2 & 87.8 & 3.1 & 0.2 & 10.0 & 1.8 \\
\hline Azerbaijan & 9.4 & 1.2 & 17.1 & 4.4 & 83.6 & 17.3 & 0.1 & -5.8 & -0.9 \\
\hline Belgium & 76.8 & 0.5 & 1.3 & 1.8 & 140.0 & 12.0 & 0.2 & 9.5 & 1.3 \\
\hline Brazil & 48.6 & 1.3 & 6.3 & 2.7 & 22.9 & 2.3 & 0.2 & 8.0 & -0.3 \\
\hline Bulgaria & 48.4 & -0.8 & 11.4 & 1.1 & 103.5 & 7.4 & 0.2 & 8.5 & -0.2 \\
\hline Canada & 129.8 & 1.1 & 2.3 & 2.3 & 65.6 & 2.7 & 0.2 & 10.0 & 1.7 \\
\hline Chile & 65.9 & 1.3 & 6.0 & 5.1 & 62.9 & 6.0 & 0.1 & 8.9 & 1.2 \\
\hline China & 107.9 & 0.8 & 15.7 & 10.0 & 51.4 & 3.8 & 0.1 & -7.0 & -0.4 \\
\hline Colombia & 33.2 & 1.6 & 11.1 & 3.7 & 33.8 & 2.9 & 0.1 & 7.4 & -0.7 \\
\hline $\begin{array}{c}\text { Czech } \\
\text { Republic }\end{array}$ & 52.7 & 0.1 & 3.8 & 1.6 & 102.4 & 4.4 & 0.2 & 9.1 & 0.8 \\
\hline Denmark & 118.6 & 0.4 & 2.3 & 1.5 & 82.1 & 2.8 & 0.3 & 10.0 & 1.9 \\
\hline Estonia & 51.4 & -0.7 & 4.4 & 5.7 & 133.8 & 7.8 & 0.2 & 7.7 & 0.8 \\
\hline Finland & 74.0 & 0.4 & 5.1 & 1.8 & 68.3 & 2.8 & 0.2 & 10.0 & 1.9 \\
\hline France & 121.5 & 0.5 & 3.4 & 1.6 & 47.0 & 2.2 & 0.2 & 9.0 & 1.4 \\
\hline Germany & 107.1 & 0.2 & 1.3 & 1.7 & 65.1 & 1.3 & 0.2 & 10.0 & 1.6 \\
\hline Hungary & 42.5 & -0.2 & 7.2 & 0.9 & 125.6 & 8.9 & 0.2 & 10.0 & 0.8 \\
\hline Indonesia & 35.8 & 1.5 & 16.0 & 5.1 & 75.3 & 1.0 & 0.1 & 1.8 & -0.7 \\
\hline $\begin{array}{l}\text { Iran, Islamic } \\
\text { Rep. }\end{array}$ & 23.8 & 1.4 & 13.6 & 4.8 & 39.2 & 0.7 & 0.1 & -3.4 & -0.7 \\
\hline Ireland & 122.0 & 1.2 & 4.9 & 3.8 & 116.1 & 10.7 & 0.1 & 10.0 & 1.6 \\
\hline Italy & 80.6 & 0.3 & 2.7 & 0.9 & 47.3 & 0.7 & 0.2 & 10.0 & 0.6 \\
\hline Japan & 194.0 & 0.2 & 1.5 & 1.1 & 23.2 & 0.1 & 0.2 & 10.0 & 1.3 \\
\hline Jordan & 72.7 & 3.2 & 3.9 & 5.3 & 111.4 & 6.1 & 0.2 & -2.4 & 0.3 \\
\hline Kazakhstan & 27.1 & 0.1 & 10.7 & 2.3 & 97.4 & 7.1 & 0.1 & -4.7 & -1.0 \\
\hline Korea, Rep. & 99.8 & 0.7 & 4.8 & 5.2 & 62.4 & 0.6 & 0.1 & 7.3 & 0.9 \\
\hline Lebanon & 71.7 & 2.2 & 6.8 & 6.7 & 69.3 & 10.7 & 0.2 & 7.0 & -0.4 \\
\hline Luxembourg & 125.4 & 1.5 & 0.7 & 3.7 & 261.5 & 17.8 & 0.2 & 10.0 & 1.8 \\
\hline Malaysia & 116.4 & 2.2 & 11.0 & 6.0 & 176.8 & 4.3 & 0.1 & 3.9 & 0.5 \\
\hline Mauritius & 62.5 & 0.9 & 7.4 & 4.7 & 136.2 & 1.7 & 0.1 & 10.0 & 0.9 \\
\hline Mexico & 22.6 & 1.6 & 4.9 & 2.9 & 47.5 & 2.5 & 0.1 & 5.8 & -0.5 \\
\hline Morocco & 45.5 & 1.3 & 16.5 & 3.8 & 59.2 & 1.6 & 0.2 & -6.3 & 0.0 \\
\hline Netherlands & 138.3 & 0.5 & 2.7 & 2.2 & 115.3 & 4.9 & 0.2 & 10.0 & 1.7 \\
\hline $\begin{array}{c}\text { New } \\
\text { Zealand }\end{array}$ & 112.3 & 1.1 & 6.8 & 2.5 & 52.2 & 2.9 & 0.2 & 10.0 & 1.8 \\
\hline Norway & 70.9 & 0.7 & 2.1 & 2.5 & 70.2 & 2.4 & 0.2 & 10.0 & 1.9 \\
\hline Pakistan & 24.3 & 2.2 & 23.8 & 4.2 & 32.7 & 1.3 & 0.1 & 2.5 & -0.7 \\
\hline Panama & 81.9 & 1.9 & 6.9 & 6.3 & 160.3 & 6.7 & 0.1 & 8.8 & -0.2 \\
\hline Poland & 30.5 & 0.1 & 5.6 & 3.7 & 60.2 & 3.0 & 0.2 & 9.1 & 0.6 \\
\hline Portugal & 118.3 & 0.2 & 4.2 & 1.6 & 59.6 & 2.9 & 0.2 & 10.0 & 1.1 \\
\hline Romania & 20.1 & -0.4 & 14.5 & 1.2 & 59.4 & 3.2 & 0.1 & 7.6 & -0.1 \\
\hline Senegal & 21.5 & 2.8 & 17.8 & 3.4 & 63.1 & 1.6 & 0.1 & 3.8 & -0.1 \\
\hline Serbia & 32.4 & -0.2 & 15.4 & -0.7 & 58.1 & 4.2 & 0.2 & 8.0 & -0.9 \\
\hline $\begin{array}{c}\text { Slovak } \\
\text { Republic }\end{array}$ & 43.6 & 0.1 & 4.9 & 2.4 & 129.1 & 3.0 & 0.2 & 8.6 & 0.4 \\
\hline Slovenia & 5736.9 & 0.1 & 3.6 & 1.8 & 111.4 & 1.6 & 0.2 & 10.0 & 1.0 \\
\hline South Africa & 126.5 & 1.7 & 3.5 & 2.6 & 50.1 & 1.2 & 0.2 & 8.5 & 0.1 \\
\hline Spain & 124.0 & 0.8 & 4.0 & 2.2 & 48.0 & 3.0 & 0.2 & 10.0 & 1.2 \\
\hline Sri Lanka & 25.8 & 1.0 & 18.0 & 5.4 & 69.2 & 1.3 & 0.1 & 5.1 & 0.1 \\
\hline Sudan & 6.5 & 2.9 & 36.4 & 4.4 & 33.4 & 5.0 & 0.1 & -5.6 & -1.5 \\
\hline Sweden & 109.9 & 0.5 & 2.3 & 2.1 & 79.0 & 4.7 & 0.3 & 10.0 & 1.8 \\
\hline Thailand & 117.9 & 0.8 & 10.6 & 4.7 & 107.6 & 3.0 & 0.1 & 6.4 & 0.2 \\
\hline Tunisia & 62.5 & 1.3 & 12.1 & 4.4 & 87.7 & 2.8 & 0.2 & -3.7 & 0.0 \\
\hline Turkey & 24.4 & 1.4 & 12.4 & 4.2 & 42.2 & 1.2 & 0.1 & 7.6 & 0.0 \\
\hline Ukraine & 25.8 & -0.6 & 14.0 & -1.4 & 103.4 & 2.8 & 0.2 & 6.4 & -0.9 \\
\hline $\begin{array}{c}\text { United } \\
\text { Kingdom }\end{array}$ & 144.7 & 0.4 & 1.1 & 2.0 & 50.4 & 3.9 & 0.2 & 10.0 & 1.7 \\
\hline $\begin{array}{l}\text { United } \\
\text { States }\end{array}$ & 168.7 & 1.0 & 1.4 & 2.4 & 23.6 & 1.4 & 0.2 & 10.0 & 1.5 \\
\hline Uruguay & 31.4 & 0.4 & 8.8 & 3.3 & 53.4 & 2.7 & 0.1 & 10.0 & 0.5 \\
\hline
\end{tabular}


Table 2. Descriptive Statistics for All Variables

\begin{tabular}{|c|c|c|c|c|c|c|}
\hline \multicolumn{2}{|c|}{ Variables } & Mean & Std. Dev & Min & Max & Observations \\
\hline CPS & $\begin{array}{c}\text { Overall } \\
\text { Between } \\
\text { Within } \\
\end{array}$ & 172.1862 & $\begin{array}{c}960.69384 \\
751.5921 \\
605.7517 \\
\end{array}$ & $\begin{array}{c}1.166045 \\
6.546282 \\
-5529.643 \\
\end{array}$ & $\begin{array}{c}15788.26 \\
5736.89 \\
10223.55 \\
\end{array}$ & $\begin{array}{c}\mathrm{N}=1311 \\
\mathrm{n}=57 \\
\mathrm{~T}=23\end{array}$ \\
\hline POPG & $\begin{array}{c}\text { Overall } \\
\text { Between } \\
\text { Within } \\
\end{array}$ & 0.9022825 & $\begin{array}{c}9803194 \\
0.86133312 \\
0.4812422 \\
\end{array}$ & $\begin{array}{c}-2.57432 \\
-0.762369 \\
-1.686991 \\
\end{array}$ & $\begin{array}{l}11.18066 \\
3.157808 \\
8.925131 \\
\end{array}$ & $\begin{array}{c}\mathrm{N}=1311 \\
\mathrm{n}=57 \\
\mathrm{~T}=23\end{array}$ \\
\hline AGRI & $\begin{array}{c}\text { Overall } \\
\text { Between } \\
\text { Within }\end{array}$ & 8.071236 & $\begin{array}{l}7.288579 \\
6.691987 \\
3.015421\end{array}$ & $\begin{array}{l}0.2961092 \\
0.6984814 \\
-3.891291\end{array}$ & $\begin{array}{l}46.80178 \\
36.44948 \\
29.36305\end{array}$ & $\begin{array}{c}\mathrm{N}=1311 \\
\mathrm{n}=57 \\
\mathrm{~T}=23\end{array}$ \\
\hline TOPENNESS & $\begin{array}{c}\text { Overall } \\
\text { Between } \\
\text { Within } \\
\end{array}$ & 77.1302 & $\begin{array}{l}48.47751 \\
43.83468 \\
21.46763 \\
\end{array}$ & $\begin{array}{c}12.33528 \\
21.6701 \\
-1.110276 \\
\end{array}$ & $\begin{array}{l}442.7595 \\
261.5093 \\
394.8966 \\
\end{array}$ & $\begin{array}{c}\mathrm{N}=1311 \\
\mathrm{n}=57 \\
\mathrm{~T}=23\end{array}$ \\
\hline GDPG & $\begin{array}{c}\text { Overall } \\
\text { Between } \\
\text { Within } \\
\end{array}$ & 3.198954 & $\begin{array}{c}4.805711 \\
1.93967 \\
4.404715 \\
\end{array}$ & $\begin{array}{c}-30.50847 \\
-1.396306 \\
-26.5673 \\
\end{array}$ & $\begin{array}{l}38.20071 \\
10.01304 \\
34.68566 \\
\end{array}$ & $\begin{array}{c}\mathrm{N}=1311 \\
\mathrm{n}=57 \\
\mathrm{~T}=23\end{array}$ \\
\hline NFDI & $\begin{array}{c}\text { Overall } \\
\text { Between } \\
\text { Within } \\
\end{array}$ & 4.034005 & $\begin{array}{l}9.190077 \\
3.698894 \\
8.426474 \\
\end{array}$ & $\begin{array}{l}-161.2402 \\
0.1404834 \\
-174.9811\end{array}$ & $\begin{array}{l}172.7155 \\
17.77489 \\
158.9746 \\
\end{array}$ & $\begin{array}{c}\mathrm{N}=1311 \\
\mathrm{n}=57 \\
\mathrm{~T}=23\end{array}$ \\
\hline GSC & $\begin{array}{c}\text { Overall } \\
\text { Between } \\
\text { Within } \\
\end{array}$ & 0.1706048 & $\begin{array}{l}0.0528244 \\
0.0494791 \\
0.0195794 \\
\end{array}$ & $\begin{array}{c}0.0314636 \\
0.0764791 \\
0.071725 \\
\end{array}$ & $\begin{array}{c}0.360623 \\
0.2951336 \\
0.3157497 \\
\end{array}$ & $\begin{array}{c}\mathrm{N}=1311 \\
\mathrm{n}=57 \\
\mathrm{~T}=23\end{array}$ \\
\hline DEM & $\begin{array}{c}\text { Overall } \\
\text { Between } \\
\text { Within } \\
\end{array}$ & 6.378185 & $\begin{array}{l}5.437572 \\
5.180863 \\
1.782309 \\
\end{array}$ & $\begin{array}{c}-8 \\
-7 \\
-5.056598 \\
\end{array}$ & $\begin{array}{c}10 \\
10 \\
13.1463 \\
\end{array}$ & $\begin{array}{c}\mathrm{N}=1311 \\
\mathrm{n}=57 \\
\mathrm{~T}=23\end{array}$ \\
\hline RL & $\begin{array}{c}\text { Overall } \\
\text { Between } \\
\text { Within } \\
\end{array}$ & 0.5137518 & $\begin{array}{l}0.9821338 \\
0.9798497 \\
0.1435453 \\
\end{array}$ & $\begin{array}{c}-1.63 \\
-1.472805 \\
-0.425152 \\
\end{array}$ & $\begin{array}{c}2 \\
1.935391 \\
-1.952626 \\
\end{array}$ & $\begin{array}{c}\mathrm{N}=1311 \\
\mathrm{n}=57 \\
\mathrm{~T}=23\end{array}$ \\
\hline
\end{tabular}

The Hausman test to decide between FE and RE models is given in Table 3:

Table 3. Hausman Test to decide between FE and RE Models with sigmamore

\begin{tabular}{|c|c|c|c|c|}
\hline \multirow{2}{*}{ Variables } & \multicolumn{4}{|c|}{ Coefficients } \\
\hline & B FE & $\mathrm{B}$ E & b-B Difference & sqrt(diag(V_b -V_B )) S.E. \\
\hline POPG & -15.69665 & -24.75033 & 9.53679 & 9.684827 \\
\hline AGRI & -3.332525 & -3.105211 & -0.2273142 & 1.492836 \\
\hline TOPENNESS & -5.838822 & -0.4088235 & -0.1750587 & 0.2710991 \\
\hline GDPG & 8.852317 & 8.319239 & 0.5330781 & 0.3980669 \\
\hline NFDI & 0.980383 & -0.526031 & 0.1506414 & 0.1705991 \\
\hline GSC & -162.8541 & 123.3665 & -286.2205 & 310.3628 \\
\hline DEM & 1.490094 & 4.897171 & -3.407071 & 3.64715 \\
\hline RL & -180.2724 & -51.15148 & -129.721 & 88.4497 \\
\hline \multicolumn{5}{|c|}{$\begin{array}{c}\mathrm{b}=\text { consistent under } \mathrm{H}_{0} \text { and } \mathrm{H}_{\mathrm{a}} \text {; obtained from xtreg } \\
\mathrm{B}=\text { inconsistent under } \mathrm{H}_{0} \text { and } \mathrm{H}_{\mathrm{a}} \text {; obtained from xtreg } \\
\text { Test } \mathrm{H}_{0}: \text { difference in coefficient not systematic } \\
\text { Chi2 }(8)=(\mathrm{b}-\mathrm{B})^{\prime}\left[\left(\mathrm{V} \_\mathrm{b}-\mathrm{V} \_\mathrm{B}\right)(-1)\right](\mathrm{b}-\mathrm{B})=4.37 \\
\text { Prob }>\text { chi2 }=0.08221\end{array}$} \\
\hline
\end{tabular}

To decide between fixed effect model or random effects model, we run simple Hausman test where the null hypothesis is that the random effect model is more efficient vs. the alternative hypothesis the fixed effect model is more efficent. The Hausman test implies (incorrectly) the use of the random effects model formulations. Because, a drawback of this Hausman test is, that the difference of covariance matrices may not be positive definite.To correct this problem we have applied the Hausman test with sigmamore option which based on both (co)variance matrices on disturbance variance estimate from efficient estimator. The Table 3 shows the value of chi-square is 4.37 which indicates that we reject the null hypothesis that the country random effect modelis more consistent and accept the alternative hypothesis that the country fixed-effects model is consistent and efficient.

As the Hausman test is in favor of Fixed Effect Model, we run regression for Panel Fixed Effect and the results are given in Table 4

Table 4. Panel Regression with Fixed Effects

\begin{tabular}{|c|c|c|c|c|c|c|}
\hline \multicolumn{7}{|c|}{ Fixed-effects (within) regression Number of obs = 1311 Group variable: cid1 Number of $\mathrm{g}$} \\
\hline CPS & Coef. & Std Err. & $\mathbf{T}$ & $\mathbf{P}>|\mathbf{t}|$ & \multicolumn{2}{|c|}{ [95\% Conf. Interval] } \\
\hline POPG & -15.69665 & 35.94221 & -0.44 & 0.662 & -86.21058 & 54.81728 \\
\hline AGRI & -3.332525 & 6.205478 & -0.54 & 0.591 & -15.50687 & 8.841815 \\
\hline TOPENNESS & -0.5838822 & 0.8331626 & -0.70 & 0.484 & -2.218439 & 1.050674 \\
\hline GDPG & 8.852317 & 4.031391 & 2.20 & 0.028 & 0.9432542 & 16.76138 \\
\hline NFDI & 0.980383 & 2.058794 & 0.05 & 0.962 & -3.941047 & 4.137124 \\
\hline GSC & -162.8541 & 892.736 & 0.18 & 0.855 & -1914.286 & 1588.578 \\
\hline DEM & 1.490094 & 9.769293 & 0.15 & 0.879 & -17.67599 & 20.65617 \\
\hline RL & -180.2724 & 124.2221 & -1.45 & 0.147 & -423.9801 & 63.43518 \\
\hline -CONS & 340.8031 & 219.875 & 1.58 & 0.121 & -90.56301 & 772.1692 \\
\hline \multicolumn{7}{|c|}{$\begin{array}{l}\text { sigma_u | } 789.23807 \text { sigma_e | } 619.17263 \\
\text { rho |. } 6190146 \text { (fraction of variance due to u_i) }\end{array}$} \\
\hline \multicolumn{7}{|c|}{ F test that all $\mathrm{u} \_\mathrm{i}=0: \mathrm{F}(56,1246)=32.94$ Prob $>\mathrm{F}=0.0000$} \\
\hline
\end{tabular}


The rho value is 0.61901 which indicates that there is $61.91 \%$ variance is due to difference across the panels (country). Moreover, it also suggests that almost all the variation in credit to private sector as percentage to GDP is due to countries initial conditions. Only the real GDP growth rate has statistically significant as the t-value indicates while population growth rate, agriculture share in GDP, trade openness as percentage of GDP, net foreign direct investment to GDP, government current spending as a percentage to GDP, democracy index and rule of law index are statistically insignificant.

The Panel Random Effect and the results are given in Table 5:

Table 5. Panel Regression with Random Effects

\begin{tabular}{|c|c|c|c|c|c|c|}
\hline \multicolumn{7}{|c|}{$\begin{array}{c}\text { Random-effects GLS regression Number of obs }=1311 \\
\text { Group variable: cid1 Number of groups }=57 \\
\text { Wald chi2(8) }=6.15 \\
\text { corr }(\text { u_i, X) }=0 \text { (assumed) Prob }>\text { chi2 }=0.6304\end{array}$} \\
\hline CPS & Coef. & Std Err. & $\mathbf{Z}$ & $\mathbf{P}>|\mathbf{z}|$ & \multicolumn{2}{|c|}{ [95\% Conf. Interval] } \\
\hline POPG & -24.75033 & 34.61281 & -0.72 & 0.475 & -92.59019 & 43.08953 \\
\hline AGRI & -3.105211 & 6.023239 & -0.52 & 0.606 & -14.91054 & 8.70012 \\
\hline TOPENNESS & -0.488235 & 0.7878231 & -0.52 & 0.604 & -1.952928 & 1.13528 \\
\hline GDPG & 8.319239 & 4.01169 & 2.07 & 0.038 & 0.4564722 & 16.18201 \\
\hline NFDI & -0.526031 & 2.051714 & -0.03 & 0.980 & -4.073888 & 3.968682 \\
\hline GFC & 123.3665 & 837.0499 & 0.15 & 0.883 & -1517.221 & 1763.954 \\
\hline DEM & 4.897171 & 9.062967 & 0.54 & 0.589 & -12.86592 & 22.66026 \\
\hline RL & -51.15148 & 87.22262 & -0.59 & 0.558 & -222.1047 & 119.8017 \\
\hline -CONS & 198.9483 & 222.0185 & 0.90 & 0.370 & -236.1999 & 634.0965 \\
\hline
\end{tabular}

The Table 6 shows the adjusted results for fixed-effects model calculated with Driscoll-Kraay (1998) standard errors are more accurate for the variance-covariance matrix due to the presence of serial as well as spatial correlation (Camarero et al, 2010).

Table 6. FE Regression with Driscoll-Kraay Standard Errors

\begin{tabular}{|c|c|c|c|c|c|c|}
\hline \multicolumn{7}{|c|}{$\begin{array}{c}\text { Regression with Driscoll-Kraay standard errors Number of obs }=1311 \\
\text { Method: Pooled OLS Number of groups }=57 \\
\text { Group variable (i): cid1 F }(7,22)=42.09 \\
\text { maximum lag: } 2 \text { Prob }>\text { F }=0.0000 \\
\text { R-squared }=0.0193 \\
\text { Root MSE }=953.6283\end{array}$} \\
\hline CPS & Coef. & $\begin{array}{c}\text { Driscoll-Kraay } \\
\text { Std Err. }\end{array}$ & $\mathrm{T}$ & $\mathrm{P}>|\mathrm{t}|$ & \multicolumn{2}{|c|}{ [95\% Conf. Interval] } \\
\hline POPG & $-65.43704 *$ & 13.41789 & -4.88 & 0.000 & -93.26404 & -37.61004 \\
\hline AGRI & $-4.875887 * *$ & 2.06687 & -2.36 & 0.028 & -9.162141 & -0.5896325 \\
\hline GDPG & 4.446572 & 2.963283 & 1.50 & 0.148 & -1.698902 & 10.59205 \\
\hline TOPENESS & $1.287962 * * *$ & 0.7027552 & 1.83 & 0.080 & -0.1694628 & 2.75387 \\
\hline NFDI & -4.73335 & 3.259008 & -1.45 & 0.161 & -11.4921 & 2.025434 \\
\hline DEM & $5.501435 *$ & 2.030456 & 2.71 & 0.013 & 1.290527 & 9.712343 \\
\hline RL & 12.30306 & 13.46104 & 0.91 & 0.371 & -15.61342 & 40.21955 \\
\hline -CONS & 133.9519* & 18.67359 & 7.17 & 0.000 & 95.22524 & 172.6786 \\
\hline
\end{tabular}

From Table 6 the estimated model is:

$$
\begin{aligned}
& (C P S)^{\wedge}{ }_{i t}=133.951-65.43704 P O P G_{i t} \\
& -4.875887 \text { AGRI }_{i t}+4.446572 G D P G_{i t} \\
& +1.287962 \text { TOPENPER }_{i t}-4.73335 N F D I_{i t} \\
& +5.501435 \text { DEM }_{i t}+12.3030679 R L_{i t}+\varepsilon_{i t}
\end{aligned}
$$

The estimated model is interpreted as:

Even in case of zero value for all the independent variables (population growth, agriculture share in GDP, real GDP growth rate, trade openness, net foreign direct investment, government spending to GDP ratio, democracy index and rule of law index) all countries expected to have credit to private sector as a percentage to GDP is 133.951. The t-value of intercept depicts that intercept term has significant effect on CPS.

For one percent (the unit is in percent) decrease in population growth, credit to private sector as a percentage to GDP (CPS) is expected to increase by $65.437 \%$ holding all other variables constant as the t- value is 4.88 shows that POPG has significant effect on CPS.
For one percent (the unit is in percent) decrease in agriculture share in GDP, credit to private sector as a percentage to GDP is expected to increase by $4.875 \%$ holding all other variables constant as t-value is 2.36 means that sagriculture share in GDP has significant effect on CPS.

For one percent (the unit is in percent) increase in real GDP growth rate, credit to private sector as a percentage to GDP is expected to increase by $4.446 \%$ holding all other variables constant.

For one percent (the unit is in percent) increase in trade openness as percentage to GDP, the credit to private sector as a percentage to GDP is expected to increase by $1.287 \%$ holding all other variables constant at t-value is 1.83 means that TOPENESS has significant effect on CPS.

For one percent (the unit is in percent) decrease in net foreign direct investment as \% to GDP, credit to private sector as a percentage to GDP is expected to increase by $4.733 \%$ holding all other variables constant.

For one unit decrease in democracy index, credit to private sector as a percentage to GDP is expected to 
increase by $5.501 \%$ holding all other variables constant at t-value is 2.17 means that DEM has significant effect on CPS.

For one unit increase in rule of law index, credit to private sector as a percentage to GDP is expected to increase by $12.3036 \%$ holding all other variables constant.

\section{Conclusion}

Financial sector development is important as it makes available funds for the development of the country by efficient allocation of financial resources. The credit to private sector can be taken as a proxy of development in financial sector. In this research report, our objective was to explore the antecedents of credit to private sector by using panel data from 1990-2012 on 57 developed and developing countries. The finding indicates that the credit to private sector in all countries depends on population growth, share of agriculture sector in GDP, Real GDP growth, trade openness as percent of GDP, net foreign direct investment as percent of GDP, government spending as percent of GDP, Dem index of democracy, and RL is index of rule of law. The results from Fixedeffects model show that all independent variables; POPG, AGRI, TOPENNESS, GDPG and DEM have statistically significant effect on CPS as percentage of GDP (results are appropriate with Caballero, R. and Krishnamurthy, A.
(2004), Hauner, D. (2006), Ali, K., Akhtar, M. F. and Ahmed, H. Z. (2011)),except NFDI and RL (results are deviating from Chakrabarti, A. (2001)and Nishat, M. and A. Aqeel (2005), due to entities and time differences). They do not have significant effect on credit to private sector. Hence, the demand and supply of credit to the private sector guarantees both financial development as well as economic growth.

\section{References}

[1] Djankov, S., Miguel, E., Qian, Y., Roland, G., \& Zhuravskaya, E. (2005). Who are Russia's entrepreneurs?. Journal of the European Economic Association, 3 (2-3), 587-597.

[2] Hausman, J. A. (1978). Specification Tests in Econometrics. Econometrica, 46, 1251-1271.

[3] Hausman, J. A. and Wise, A. D. (1977). Social Experimentation, Truncated Distributions, and Efficient Estimation. Econometrica, 45, 319-339

[4] Caballero, R. J., \& Krishnamurthy, A. (2004).Smoothing sudden stops. Journal of Economic Theory, 119 (1), 104-127.

[5] Rubaszek, M., \&Serwa, D. (2012). Macro prudential Research Network.

[6] Anthony, K. A., \& Frank, G. S. (2013).Determinants of credit rationing to the private sector in Ghana. African Journal of Business Management, 7 (38), 3864-3874.

[7] Rutherford, S. (2000). The Poor and their Money. New Delhi: Oxford University Press. 